\title{
Antiguo Testamento y Derechos Humanos
}

\author{
Rafael de Sivatte, \\ Centro de Reflexión Teológica, \\ San Salvador.
}

\section{Introducción}

Cuando el estudioso de la historia del pueblo de Dios se plantea cuál es el origen de la existencia de Israel, descubre que es a partir de un derecho humano - el derecho a la liberad y a la vida digna- conculcado, pero finalmente ejercido por unos grupos humanos, que se forma el pueblo de Israel. Estos grupos comprenden que es Dios mismo quien no soporta que tal derecho sea violado. Esto es lo que se nos intenta transmitir en los cinco primeros capítulos del libro del Exodo. No pueden ser más claras en este sentido las expresiones que aparecen en Exodo 3, 7-8 en boca de Dios:

Bien vista tengo la aflicción de mi pueblo en Egipto, y he escuchado su clamor en presencia de sus opresores; pues ya conozco sus sufrimientos. He bajado para librarle de la mano de los egipcios y para subirle de esta tierra a una tierra que mana leche y miel...

Muchos grupos humanos estaban viviendo, de diferentes maneras, esta aflicción, eslos sufrimientos y esta opresión: unos, convertidos en Egipto en esclavos forzados a trabajar para el gobierno egipcio; otros, continuamente molestados por los retenes egipcios, en su caminar nomádico por los desiertos; unos terceros, que se dedicaban a la agricultura en la zona sureste de Canaán, visitados periódicamente por los ejércitos egipcios quienes les cobraban unos fuertes impuestos sobre sus tierras y sus ganados, cuando no les robaban directamente.

Todos estos grupos vivieron hacia los aftos 1250 a. C. la liberación de estas situaciones en que sus derechos humanos básicos eran violados y comenzaron a compartir el estreno de su libertad y lo que esto significaba. Fue en torno a esta experiencia de haber alcanzado que se respetasen aquellos derechos humanos básicos, que se empezaron a unir, hasta llegar a formar una nación, sobre todo 
en el centro y en cl sur de la tierra de Canaán. Así surgió, pues, Israel.

Lo antcrior explica que Israel fuese descubriendo, luego, poco a poco, a io largo de su historia, la importancia que tenía el vivir respetando unos derechos humanos consecuentes con aquella experiencia primera de defensa por parte de Dios de un derecho fundamental como es el derecho a la libertad y a la vida digna, a la residencia en una tierra, a la propia vida de fe. Vamos a ver a continuación esta historia de la defensa de los dcrechos humanos en el Antiguo Testamento. Insistiré algo más en la defensa que hacen los tres grandes códigos legales del Antiguo Testamento, complementándola con las defensas hechas por los profetas y con las que aparecen en las reflexiones sapienciales.

\section{Historia de la defensa de los derechos humanos en el Antiguo Testamento}

\section{En tiempo de David y Salomón, en Jerusalén (1000-931 a.C.)}

Nos situamos en el liempo del rey David, en la capital del reino de Israel, Jerusalén, hacia el año 1000 a.C. Tanto en el reinado de David como en el de Salomón, su hijo, no parece que el derecho a la vida fuese el más respetado. De hecho tenemos constancia (cfr. 2Sam 11-12) del horrible crimen perpeurado por el mismo rey David, quien no sólo le robó a uno de sus súbditos la mujer, sino que acabó asesinándolo para poder así casarse públicamente con ella.

Es en este contexto histórico en el que algunos creyentes (los llamados Yahvisias) recogen la historia de un asesinato, que se había convertido casi en una historia mítica, y la incluyen en su narración de los orígenes en Génesis 111. Tras el relato del paraíso-caída, en que nos presentan su reflexión creyente sobre la realidad del ser humano (se deshumaniza cuando quiere hacerse dios), narran, en Génesis 4, 1-16, el asesinato de Abel, cometido por su hermano Caín. Es el primer pecado real narrado en la historia de los orígenes: el hermano mata, por envidia y por ambición, al propio hermano.

¿Cómo reacciona Dios ante ello? El texio nos explica cómo él no soporta el clamor de la sangre calda sobre el suelo y cómo, ante la gravedad del asunto, echa una maldición contra el asesino, cosa que no ocurría en la narración de Adán y Eva; en ésta se maldecía el entomo de los personajes, pero no a los personajes mismos. La narración acaba, sin embargo, con una promesa lanzada por Dios de protección, en el futuro, de la vida de Caín, el asesino.

Podemos decir que es la primera defensa del derecho a la vida que encontramos en la historia del pueblo de Dios. En los momentos siguientes volveremos a encontrar otros textos en que este derecho u otros derechos humanos son defendidos. 


\section{En tiempo del rey Ajab de Israel, en el norte (850 a.C.)}

Tras la ruptura del pás en dos, a la muerte de Salomón, hacia el año 850 a.C. reina en Israel un rey que, por motivaciones políticas, cae en el "baalismo" más burdo; de hecho se había casado con la hija de un sacerdote fenicio llamada Jezabel y se había convertido en adorador de lodos los dioses renicios y cananeos. Se trata dcl rey Ajab.

Aparte de la persecución a que somete a los creyentes en Yahvch y a sus profelas, llega a su punto culminante cuando, basado precisamente en su adoración de las divinidades del país o baales, comete uno de los crímenes más horribles de los que se han narrado en la historia. En IReyes 21 se narra cómo el rey manda asesinar a un pobre hombre sencillamente porque éste no le quiere vender una viña familiar. Tal acción provoca, según el texto bíblico, la inmediata reacción del profcusmo, el cual, en la persona del legendario Elías, denuncia con toda fuerza al rey ( $c f r$. 1 Re $21,17-24$ ) su crimen. Este crimen levanta inmediatamente el juicio condenatorio de Dios: es Yahveh mismo el que da su sentencia, en la cual queda bien claro y patente cuál cs su postura frente a la violación del derecho que tiene a la vida lodo ser humano.

A raíz de actuaciones como la que acabamos de constatar, la cual, posiblemente, no es más que una muestra de otras muchas violaciones a los derechos humanos en ticmpo del rey Ajab dc Israel, parece que se empieza a recoger en el Código de la Alianza (Ex 20, 22-23, 19), una serie de leyes esenciales que tienen como intención regular las relaciones que se deben dar entre los miembros del pueblo y su Dios, la convivencia ciudadana y nacional, y los principales derechos que se desprenden de la vida en comunidad y en sociedad. Antes de pasar a ellos es importante tener en cuenta que el tiempo histónico y la cultura en la que se recogen estas lcyes suponen una situación muy diferente a la nuestra en muchos sentidos.

Voy a analizar brevemente algunos fragmentos de este Código de la Alianza para descubrir cómo en ellos va apareciendo una legislación que intenta de ‘ender algunos de los derechos fundamentales de los seres humanos. Quiero añadir que voy a intentar hacer una sencilla agrupación de estas lcyes en defensa de los derechos humanos por temas, en cl mismo orden en que aparecen en el Código. Lo mismo haré luego con los otros códigos.

\section{a) Sobre la libertad y la esclavitud}

Ex 21, 1-11: Se acepta como algo ordinario la esclavitud. Lo interesante, sin embargo, es que se intenta regular para que no sea desmesurada.

Ex 21, 16: Se declara digno de muerte aquél que se dedica a raptar a

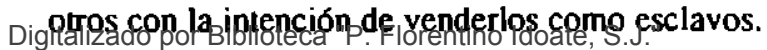

Universidad Centroamericana José Simeón Cañas 
b) Sobre la vida

Ex 21, 12-17: Sc habla de la institución de las ciudades de refugio. A la pregunta de con qué linalidad se crean talcs ciudades, se responde que para los casos en que se ha cometido un homicidio involuntario; en tales casos las ciudades sirven para que el homicida involuntario se pueda refugiar y así no sea víctima del vengador de sangre, evitando de esta manera otra muerte.

Ex 22, 1-2: Se habla del caso de robo. En tal caso se mucsura una gran preocupación por evitar dentro de lo posible el derramamiento de sangre. De ahí viene la casuística siguiente. Si el robo es a plena luz, se da por supuesto que el que encuentra al ladrón mientras esló robando liene medios para defender la propiedad sin llegar al extremo de matarlo. No tiene derecho por tanto a quitar la vida al ladrón; y, si lo hace, cae bajo la pena que le corresponde a un asesino (los familiares del ladrón mucrto, por tanto, tendrían cl derecho de aplicarle la ley de la venganza de sangre). Muy diferente es el caso cuando el intento de robo se da por la noche y parece que no es fácil defender la propicdad evitando el Ilegar hasta el cxtremo de matar al ladrón. Al decir que en este caso los parientes no tendrían derecho a la venganza de sangre, se estaría mostrando tambićn la gran preocupación por defender la vida, aunque aqui se trata de la defensa de la vida del que ha malado el ladrón sin poderlo evitar, frente a los parientes del difunto que querrian aplicar la ley de la venganza de sangre, derramando asi más sangre y acabando con otra vida.

\section{c) Sobre el respeto a los padres}

Ex 21, 15. 17: Se habla, a continuación, del maltrato o de la maldición del padre y de la madre; el que haga tal cosa es considerado digno de mucrte.

d) Sobre la indemnización

Ex 21, 18-36: Se encuentran cn csta unidad una serie de leyes que exigen la indemnización cuando se le ha hecho algún daño al prójimo.

Ex 21, 37; 22, 2b-3:

El caso planteado en esta unidad es el del robo de un animal;

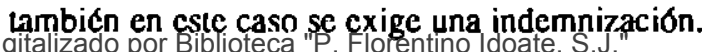


Ex 22, 4-14: El tema aquí vuelve a ser el de la obligación de resarcir por un dafio causado.

Ex 22, 15-16: El caso que se presenta es el de la violación de una virgen. En este caso se debe pagar la dote que se acostumbra a pagar por una esposa y tomarla como mujer. Pero si el padre de la virgen no quiere entregarla, entonces el violador pagará la dote de las vírgenes y ya esta.

e) Sobre el cuidado por aplicar bien y matizadamente la justicia

Ex 22, 1-2 Este texto ya usado antes para descubrir la preocupación por defender al máximo la vida, dentro de las leyes y concepciones de aquel tiempo, manifiesta también la gran preocupación porque la justicia se aplique con todos sus matices, teniendo en cuenta los agravantes y atenuantes de las acciones. El caso concreto que se plantea es el de quien para delender su propiedad mata al ladrón que intentaba robarle: es diferente el juicio que se da si el ladrón estaba realizando su robo durante el día, a plena luz, o bien durante la noche.

Ex 23, 1-2.6-8: En la última unidad dentro del Código de la Alianza, en la que se trata de temas relacionados con la defensa de los derechos humanos, se da una serie de mandatos para que se colabore con fuerza a que haya justicia. Se prohíbe por ejemplo que se de falso testimonio para ayudar al que no liene razón. Se prohíbe también seguir a la mayoría en un juicio, si es contra justicia. Al juez por su parte se le exige no absolver al malvado y no dejarse comprar con regalos.

\section{I) Sobre los pobres y marginados}

Ex 22, 20-26: Tres temas aparecen en esta pequeña unidad.

En primer lugar, se habla de los derechos y de la dignidad que tienen el inmigrante, la viuda y el huérfano. Yahveh se declara vengador de las vejacioncs sufridas por ellos.

Se prohíbe a continuación prestar dinero a interés al pobre. De fondo está la conciencia de que è pobre siempre necesila de crédito para poder subsistir; si estos préstamos se le hacen con intereses, el pobre nunca puede salir de su situación de pobreza, cosa a la que tiene derecho.

El tercer tema que se plantea es el de la prenda dejada por el pobre cuando no puede pagar una deuda. La prenda más

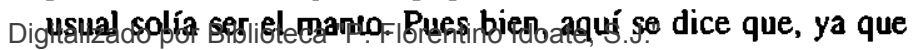
Universidad Centroamericana José Simeón Cañas 
el manto es lo único que el pobre puede dejar como prenda, el acreedor, por respeto a aquél y también por la necesidad objetiva del pobre de tener algo durante la noche para poderse abrigar, al caer el sol debe devolverle al pobre el manto que éste habla dejado como prenda.

Ex 23, 9: $\quad$ Finalmente, se exige que no se oprima al inmigrante, que no se le quite la vida al inocente y que, en último término, se defienda el derecho del pobre.

\section{g) Sobre la relación con el enemigo}

Ex 23, 4-5: $\quad$ Aparecen en estos versos unos mandatos de respetar al enemigo. En este sentido se dice que se debe devolver al enemigo su animal, cuando uno lo encuentra, o que se debe ayudar al enemigo cuando su asno se ha caído al suelo bajo el peso de la carga.

Como se ha visto analizando estos textos del Código de la Alianza, en él vamos descubriendo las primeras defensas legales de los derechos humanos. Profetas y legisladores, por tanto, van viendo con claridad cuán fundamental es para vivir la fe en Yahveh respetar y defender los derechos de los miembros de la comunidad y de los inmigrantes.

\section{En Israel y Judá, en momentos de euforia (740-700 a.C.)}

Pero los intereses y ambiciones de algunas minorías, los egoísmos y deseos de enriquecimiento, los miedos a perder los privilegios del poder, etc., provocan a continuación siluaciones, tanto en el reino de Israel como en el de Judá, en que, desde el rey hasta los últimos que tienen algún tipo de poder o autoridad (sacerdotes, minisuros, servidores de la corte, militares, jueces, comerciantes, etc.), todos faltan con frecuencia, de una manera u otra, a los derechos fundamentales de las personas, y de un modo especial de las personas más pobres y desprotegidas. Esto ocurre sobre todo en las cortes de Jeroboam II, en Samaria, y de Jotam, en Jerusalén, en tomo a los afos 740 . Se podría decir, en resumen, que se pisotean continuamente los derechos de los más pobres.

Lo primero que hacen los creyentes de este tiempo es revisar las antiguas leyes del Código de la Alianza para irlas adaptando a las nuevas situaciones, cada vez más llẹnas de complejidad. El Código Deuteronómico es el fruto de tal revisión. Lo encontramos en Deuteronomio 12-26. Entresacamos de él las principales prescripciones de tipo social. Y lo vamos a hacer siguiendo los mismos apartados utilizados en las agrupaciones por temas del Código de la Alianza. 


\section{a) Sobre la libertad y la esclavitud}

Dt 15, 12-18: Se legisla aquí sobre el derecho que tienen los hermanos hebreos, que se han tenido que vender como esclavos, a recuperar la liberad después de seis años de servicio y a recibir algo del frulo de su trabajo, según como Dios haya bendecido al amo; y esto, en justicia ya que su servicio tiene un valor superior al de un doble salario de jomalero.

Di 23, 16-25 Deber de acoger y no entregar al antiguo amo el esclavo que ha conseguido huir. Deber de prestar sin usura y sin cobrar interés; no se trata de hacer negocio con los préstamos, sino de dar posibilidades al hermano. Derecho a comer los frutos del campo del prójimo, aunque no a acumular.

Di 24, 7: Se sentencia duramente a quien rapta a alguien para negociar con su libertad, vendiéndolo como esclavo.

b) Sobre la vida

Di 19,1-13: Se habla aquí de la obligación de crear ciudades de relugio de modo que, en caso de homicidio involuntario, los homicidas puedan refugiarse en aquellas ciudades elegidas para poder asi escapar a la venganza de sangre, ya que en tal caso el aplicar la ley de la "venganza de sangre" sería a costa de derramar sangre inocentc. No ocurre lo mismo en el caso del asesino que ha matado con intención y con odio; en este caso, dicho asesino no tiene derecho al uso de las ciudades de refugio.

Dt 22, 8: Se exige que uno ponga barandas en la terraza de la casa para evilar así que pueda darse un accidente morlal. Se quiere evitar además que por un descuido muera alguien y los parientes de éste se crean con derecho a practicar la venganza de sangre contra quien consideren responsable del accidente monal, es decir, quien no ha puesto barandas en la terraza de la casa.

\section{d) Sobre la indemnización}

Di 22, 28-29: En medio de una seric de leyes casuísticas en relación al adulterio y la fornicación, de las que ya trataré en un apartado posterior, se habla del hombre que viola a una virgen y de la indemnización que debe pagar, tanto en lo que se refiere a lo económico como en el compromiso que debe tomar en el fuluro, que se concrela en la obligación de casarse con ella. 
En esta misma línea de la indemnización está la ley del talión ("ojo por ojo, diente por dientc, vida por vida"), aunque el sentido de dicha ley es más amplio.

\section{e) Sobre el cuidado por aplicar bien y matizadamente la justicia}

Di 16, 18-20: Se muestra aquí la preocupación porque los jueces cumplan con sus deberes, es decir, que hagan juicios justos, no tuerzan el derecho, no hagan acepción de personas, no acepten soborno y busquen siempre y sólo la justicia.

Di 19, 15-20: Se muestra de nuevo la gran preocupación porque se haga siempre justicia y porque no se haga uso de testigos falsos para absolver o condenar.

Dt 22, 22-29: Aparte del tema de la indemnización que se debe pagar por haber violado a una virgen, del que ya he hablado en el apartado sobre la indemnización, se recogen aquí, en forma casuística, una serie de leyes en relación al adulterio y la formicación. No sicmpre la pena debe ser la misma; se debe distinguir. Si se trata de una mujer casada, deben morir los dos. Si se trata de una joven virgen prometida, muerte también de los dos si ella pudo pedir auxilio y no lo hizo; muerte de él sólo si ella no tuvo oportunidad de pedir auxilio. Si se trata de una joven virgen no prometida, él debe pagar por ella una indemnización y la debe tomar como esposa ya que la ha violado. Toda esta casuística indica una vez más la gran preocupación porque se tengan en cuenta todos los agravantes y atenuantes a la hora de aplicar al justicia.

Dt 24, 17; Deber de no torcer el derecho del inmigrante y del huérfano.

25, 1: Derecho del que tiene la razón a que se la den en los tribunales de justicia.

Dt 27, 18-19: Maldición contra quien no respete los derechos de los ciegos, los inmigrantes, los huérfanos y las viudas.

\section{n) Sobre los pobres y marginados}

Dt 14, 27: En el contexto de la ofrenda del diezmo anual y de la celebración unida a ella, se legisla la obligación de no dejar abandonado al levita, uno de los grupos pobres de aquel tiempo.

Dt 14, 29: En el contexto, en este caso, de la ofrenda del diezmo trienal, se habla del derecho del levita, del inmigrante, del huérfano y de la viuda a comer hasta saciarse. 
Dt 15, 1-11: El tema de este fragmento es el del deber de la remisión sabática, es decir, de que el acreedor cada siete años debe devolver la prenda personal del deudor pobre (a veces se trataba del propio hijo que había pasado a ser esclavo del acreedor). En tal contexto, se alirma que, a pesar de que no debería haber pobres, ya que la tierra es bendición de Dios para todos, si los hay, no les deben cerrar el corazón ni deben calcular que ya se acerca el año sabático de remisión de las deudas para no prestarles; deben ayudarles siempre de buena gana.

Di 16: $\quad$ En este capítulo en que se habla del derecho a regocijarse en presencia de Yahveh en las diferentes fiestas, se muestra la preocupación porque sean todos quienes tengan derecho a hacerlo: la familia entera, el sicrvo y la sicrva, el levita, el inmigrante, el hućrfano y la viuda.

DI 24, 10-13.17-22:

Deber de respetar los instrumentos de trabajo del pobre y no recibirlos como prenda por sus deudas. Deber de respetar la dignidad de quien se ha tenido que entrampar económicamente por no poder pagar una deuda (no se debe entrar a su casa para tomar una prenda de su deuda, sino que se debe esperar a que él mismo la dé). Deber de devolver al atardecer al pobre el abrigo que no ha tenido más remedio que dar como prenda por sus deudas. Deber de no torcer el derecho del inmigrante y del huérfano. Derecho de la viuda a que no tomen su vestido de abrigo como prenda por sus deudas. Derecho del inmigrante, el huérfano y la viuda a lo que ha quedado de la mies, de los olivos o de la viña en el campo después de la cosecha.

Dt 26,12 : Derecho del inmigrante, la viuda y el huérfano a recibir el diezmo trienal, como una medida para ayudarles en su pobreza.

Di 27, 18-19: Maldición contra quien no respete los derechos de los ciegos, los inmigrantes, los huérfanos y las viudas.

\section{h) Sobre los campos familiares}

Di 19, 14: Esta breve ley se refiere al deber de respetar los límites del campo familiar del prójimo; son sagrados.

Digitalizado por Biblioteca "P. Florentino Idoate, S.J."

Universidad Centroamericana José Simeón Cañas 
i) Sobre el deber de enterrar a los muertos

Di 21, 22-23: Sc habla aquí del deber de cntcrar con prontitud los cadáveres, aun cn el caso de que se trate de ajusticiados; más aún si sc trata de inocentes.

j) Sobre el deber de devolver al prójimo lo hallado

Di 22,1-3: Se ordena devolver al prójimo sus objetos encontrados, como pueden ser el buey, cl asno, el manto o cualquier otro objeto de su propiedad.

k) Sobre el deber de ayudar al hermano en dificultades

Dt 22, 4: Se pone como deber ayudar al hermano cuando uno encuentra que su bucy o su asno han caido en el camino.

I) Sobre el salario justo

Dt 24, 14-15: Derecho del jornalero humilde, ya sea un hermano, ya sea un inmigrante, a un salario justo.

m) Sobre la honradez comercial

Dt 25, 13-16: Deber de usar medidas y pesas auténticas o, dicho de otra manera, de no cometer fraude comercial.

Es de notar, al acabar este sencillo análisis por temas de las leyes para defender los derechos humanos en el Código Deuteronómico, que la fundamentación y la motivación que más aparece en dichas leyes es que el pueblo debe "recordar" que fue esclavo del dominio egipcio y Yahveh lo libcró; de ahí se desprende que deba vivir defendiendo los derechos humanos.

Contcmporáneamente a las anteriores formulaciones del Código Deuteronómico, también algunos profetas formulan sus denuncias a la conculcación de dichos derechos y al no cumplimiento de los deberes sociales. El primero es Amós. En él encontramos un texto muy significativo (Am 1, 1-2,16) que viene a ser el resumen de todas sus denuncias, esparcidas a lo largo de toda su breve actuación profética.

Comienza Amós por denunciar a las naciones colindantes de Israel (lo hace quizás para que le tomen por un profeta cúltico y profesional al que no se teme porque se sabe que no va a decir nada en contra de los propios intereses, ya que está bien pagado). Y las denuncia porque han faltado gravernente a los derechos humanos: han triturado con trillos de hierro a sus enemigos, han deportado poblaciones enteras para hacerlas esclavas y para poder comerciar con ellas, han perseguido sin piedad a sus países hermanos con la espada, han reventado tras la Digitalizado por Biblioteca "P. Florentino Idoate, S.J."

Universidad Centroamericana José Simeón Cañas 
victoria a las mujeres encinta de los países vencidos en una guerra imperialista y de agresión, han quemado los huesos del rey al que han vencido en combatc. Estas son las graves violaciones de los derechos humanos realizadas por los vecinos de Israel.

Pero luego pasa a las denuncias de lo que está haciendo Israel mismo; objelivamente los actos realizados por Isracl no son tan graves, aunque lo son mucho más porque los hace una nación que se las da de creyente en el Dios Yahveh y que continuamente usa el nombre de dicho Dios.

Veamos cuáles son estas denuncias: los jueces se dejan comprar por pequcños regalos y venden así al justo y al pobre dejándolo caer en la esclavitud, en beneficio del rico y del injusto; los poderosos oprimen al pobre y acaban con la vida de los indelensos, a quienes acaban chafando contra el suelo, como se hace con un gusano; los amos de la casa no respetan la dignidad de la sirvienta y se aprovechan de su posición de amos para utilizarla en sus deseos sexuales, como si fuesc un objeto más de su propicdad; los acreedores a quicnes los deudores han entregado, como mandaba la ley, sus prendas de abrigo como señal de aceptación de la dcuda, no devuelven cales prendas a los pobres por la noche para que se puedan abrigar contra cl frío, tal como tambićn manda la ley, y encima se van a celebrar fiestas "junto a cualquier altar" recostados sobre tales prendas; las autoridades, bajo apariencia de legalidad (multas impuestas o confiscación de bienes de un deudor que no puede pagar), usan el dinero o los objetos confiscados para celebrar liestas en honor de "su dios"; se intenta hacer callar a los profetas quienes son los únicos que se atreven a recordar lo que deben hacer para cumplir la voluntad de Dios y se intenta también que los nazireos que con su vida austera recordaban la necesidad de seguir siempre manteniendo el espíritu nomádico y caminante junto a Dios, dejen de vivir en tal austeridad para que dejen de ser interpeladores; la violencia, la rapiña, el lujo, el despilfarro, el fraude comercial, los banquetes insultantes, etc., están a la orden del dia. Todas estas acciones son consideradas unas graves violaciones de los derechos humanos que el Dios libertador de la opresión, el Dios acompanante del pueblo y donador de la tierra, el Dios que sigue suscitando profetas y nazireos que interpelen al pueblo a seguir siendo fieles, no puede soportar de ninguna manera (véase Am 2, 6-16; 3, 9-10.15; 4, 1; 5, 7.10-12; 6, 12; 8, 4-6).

Contemporáneo del mismo Amós, el profeta Oseas denuncia las mismas realidades que aquć, afiadiendo además algunas otras denuncias que son propias de la nueva coyuntura que a él le toca vivir: las guerras fratricidas entre Israel y Judá, movidas por las presiones de las superpotencias; las idolátricas alianzas militares con las mismas; los golpes de Estado realizados por los militares por su ambición de poder. En el fondo, Oseas ve tales acciones como reales violaciones contra el derecho del pueblo a vivir en paz, tanto nacional como internacionalmente. Acaba el profela diciendo que no ve otra solución que el volver Digitalizado por Biblioteca "P. Florentino Idoate, S.J."

Universidad Centroamericana José Simeón Cañas 
todos juntos a Dios para así hacer justicia y llegar a amar solidariamente.

Del mismo tiempo que los anteriores profetas, pero en torno a Jerusalén, Isalas también es sensible a situaciones parecidas y denuncia con fuerza tales violaciones de los derechos humanos. Enumeremos esas violaciones denunciadas: las manos están llenas de sangre de inocentes; no hacen justicia; no dan sus derechos al oprimido, al huérfano y a la viuda; los jefes son ladrones, se dejan sobomar, van tras los regalos, no hacen justicia al huérfano y a la viuda; las señoronas de la corte despilfarran y viven rodeadas de lujos; hay quienes acaparan riquezas y campos, quienes se cncandilan por el vino y las ficslas, quienes están llenos de engaños y cngañan a los demás y encima le piden cuentas a Dios y exigen que actúe en su favor, quienes se creen los únicos capaces de aconsejar al rey y no le dan otros consejos que los que nacen de sus propios intereses, quiencs desde su afición por la bebida se alienan y no cumplen con su obligación de hacer justicia, quienes desde cl poder que tienen como jueces atropellan a los débiles y a los huérfanos y viudas (vćase Is $1,16 a .21-23 ; 3,12-4,1 ; 5,8$ $24 ; 10,1-4)$.

El profeta llama en consecuencia a todo lo contrario, a una conversión radical de todas estas actitudes y acciones en contra de los derechos humanos. Habla, en este contcxlo, de la fidelidad de Dios, quien enviará a su "ungido", su "mesías", para cumplir su papel de hacer justicia a los desprotegidos en contra de los poderosos y de conseguir una paz. justa y estable para todos y a todos los niveles (véase Is 8, 23-9, 6; 11, 1-9).

También el profeta campesino Miqueas, en torno a Judá, sigue la misma linea de actuación y de denuncia-anuncio que los anteriores. Los objelos de sus denuncias de las violaciones de los derechos humanos son: quienes son poderosos y se pasan las noches maquinando cómo cometer injusticias al día siguiente, quienes codician y acaparan campos y casas, quienes son violentos, quienes son jefes y con su injusticia acaban por devorar a las mayorias populares, quicnes edifican la ciudad con sangre (y no cualquier ciudad, sino la parte sagrada de la ciudad de Jerusalén, es decir, Sión), quicnes se dejan sobornar y actúan movidos sencillamente por el dinero, quienes cometen fraudes comerciales y se enriquecen empobreciendo a los que vienen a comerciar con cllos, quienes no tienen otro pensamicnto que el dinero (véase Mi 2, 1-2; 3, 1-3.5.9-11; 7, 1-6).

Como Isaías, también él sc atreve a anunciar que Dios sigue siendo liel y que hará surgir de la humilde villa de Bclén un pastor que producirá la paz. Pero insiste en que para que ello se haga realidad es necesario que todos se pongan a pracuicar la justicia, a amar con toda ternura y a caminar con toda humildad en compañía de Dios (véase Mi 5, 1-5; 6, 1-8).

Complementando esta visión de los códigos legales y de los profetas, es interesante constatar que también la visión de la sabiduría popular y coriesana Digitalizado por Biblioteca "P. Florentino Idoate, S.J."

Universidad Centroamericana José Simeón Cañas 
contemporánea va en la misma línea. Sólo quiero recoger aqui unas pocas sentencias:

Oprimir a los débiles es ofender a su Creador; pero ser bueno con los desdichados lo honra (Pr 14, 31).

Yahveh derriba la casa de los soberbios, pero levanta los cercos de la viuda (PT 15, 25).

El que hace burla del pobre ofende a su Creador, el que se ríe de un desdichado no quedará impune (Pr 17,5).

No cambies los anliguos límites que us padres establecicron (Pr 22, 28).

No cambies los límites antiguos familiares, no te apoderes del campo del huéffano, porque su "vengador" es poderoso; él asumirá su querella en tu contra (Pr 23, 10-11).

No es bueno en los juicios hacer distinción de las personas (Pr 24, 23).

\section{En la reforma de Josías ( 625 a. C.)}

La elapa anterior acabó en Jerusalén con una pequeña reforma propiciada por el rey Ezequías, una reforma a la que siguió por parte del hijo y del nieto de dicho rey una fuerte persecución de los profetas y creyentes que acabó en la mayoría de los casos con su anulación. Tras ello, sin embargo, retornó el espíritu reformador con la subida al trono de Jerusalén del biznicto de Ezequías, el jovencito Josías, quien apoyado por el profeta Solonías inició una reforma que se fundamentó en la nueva y actualizada edición del "Código Deuteronómico", del que ya hemos hablado antes con detenimiento. No voy a repetir ahora lo dicho anteriormente sobre dicho código. Sólo voy a decir algo sobre el profeta Solonfas que fue quien impulsó tal reforma y que lo hizo tambićn por la experiencia de las violaciones de los derechos humanos vividas durante los reinados de Manasés y Amón y que seguian coleando en los inicios del reinado del Lodavía nifio Josías.

He aquí las denuncias de Sofonias que se centran en que la ciudad entera se ha hecho opresora, en que sus príncipes son leones rugicntes y sus jueces son como leones de la tarde que no dejan un hueso para la mañana, en que sus cortesanos siguen las modas y la política asirias, en que quienes están en tomo al rey son violentos y fraudulentos. Todo lo anterior le hace clamar por el cambio en favor de los humildes del país, los únicos con los que Dios está dispuesto a seguir:

... castigaré a los ministros, a los hijos del rey y a todos los que se visten a la moda extranjera. Les daré también su merecido a todos los que pasan por el umbral sin pisarlo y a los que amontonan en la casa de su Señor el producto

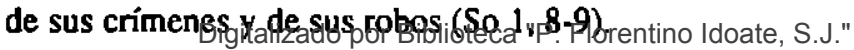

Universidad Centroamericana José Simeón Cañas 
¡Ay de la rebclde, de la manchada, de la ciudad opresora! No ha hecho caso a mi llamado, ni ha querido aceptar mi corrección, nunca ha tenido confianza en Yahveh ni se ha acercado a su Dios. Sus reyes se comportan como leones que rugen, sus gobernantes son como lcones noctumos que no guardan ni un hueso para cl día siguiente. Sus profctas son unos charlatanes que andan engañando, sus sacerdotes profanan las cosas santas y no respetan la ley (So $3,1-4)$.

Busquen a Yahveh todos ustedes, los pobres del país, que cumplen sus mandatos, practiquen la justicia y sean humildes y asi tal vez encontrarán refugio el día en que Yahveh venga a juzgar (So 2, 3).

Esc día no tendrás que avergonzarte de todas esas veces en que me traicionaste, pues de en medio de ti yo arrancaré a aqucllos que se jactan de su orgullo y tú no seguirás vanagloriándote en mi montaña santa. Dejaré subsistir dentro de li a un pueblo humilde y pobre, que buscará refugio sólo en Dios. Aquellos que queden de Isracl no se portarán injustamente ni dirán más mentiras ni se hallarán en su boca palabras engañosas. Podrán alimentarse y descansar sin que nadie les moleste (So 3, 11-13).

Tal clamor tuvo como fruto la mencionada reforma deuteronómica de Josías y la actualizarión del Código Deuteronómico.

Tal reforma, sin embargo, acabó con un rotundo fracaso, cuando el rey Josías murió a manos del faraón egipcio.

\section{El reinado de Joaquín I (605 a. C.)}

El faraón egipcio que mató a Josías convirtió a Judá en su país vasallo y nombró como rey en Jerusalén al hijo primogénito de Josías, cuya fama de ambicioso, injusto y violador de los derechos humanos le dio al faraón la seguridad de que siempre lo tendría en sus manos. Electivamente, Joaquín I empezó a gobemar e inmediatamente demostró que la base de su gobierno scría la violación de los derechos humanos, de un modo especial de los derechos humanos de los pobres.

Inmedialamente surge en Jerusalén el inmigrante Jeremias, quien comienza a denunciar dicha violación. Dos acciones de Jeremías son especialmente significativas en dicha denuncia. Veámoslas.

En su famoso discurso en el templo contra cl templo y los cultos falsos en él realizados el profeta hace una fuene denuncia contra quienes roban, matan, no hacen justicia, oprimen a los marginados y débilcs (el inmigrante, el huérfano y la viuda) y derraman sangre inocentc. Todo esto no lo puede soportar Dios, afirma el profela, y por esto se desentiende de dicho templo; no va a mover un solo dedo en su favor y más bicn lo va a hacer en su contra (vćasc Jr 7, 1-15).

Digitalizado por Biblioteca "P. Florentino Idoate, S.J."

Universidad Centroamericana José Simeón Cañas 
En el mensaje que dirige a los reyes, y de un modo especial al rey Joaquín I, el profeta insiste en cuál es el papel esperado de un rey, a saber, hacer justicia; salvar al oprimido de manos del opresor; practicar el derecho y la jusucia; no atropellar al inmigrante, al huérfano y a la viuda; no hacer violencia ni derramar sangre inocente. Pasa a continuación a denunciar sobre todo a Joaquín I porque edifica su casa sin justicia y sus pisos sin derecho, se sirve de balde de su prójimo y sin pagarle el salario, edifica palacios lujosos como si esto fuera lo que le hiciera rey, sólo mira por su provecho e interés, derrama continuamente la sangre de los inocentes, cuyo único "pecado" es protestar por tales violaciones cometidas por el rey. Acaba repitiendo cuál es el papel del auténtico rey que no es otro que practicar la justicia y defender a los marginados para que todos puedan vivir dignamente (véase Jr 21, 11-23, 8). Es bien significativo en esta línea lo que Jeremias dice del buen rey Josias, contraponiéndolo a lo que hace su hijo el rey Joaquín I (véase Jr 22, 13-19):

Tu padre, ¿no comía y bebía? Pero el praclicó la justicia: juzgó la causa del cuitado y del pobrecillo. Y ino es esto conocerme?, dice Yahveh. Pero tus ojos y tu corazón no están más que a tu granjería y a la sangre inocente para derramarla, y al atropello y al fraude para apropiarte de todo.

El profela es perseguido a muerte por lodos sus desenmascaramientos y no consigue evitar que la sociedad de Jerusalén se desmorone hasta caer en manos de Nabucodonosor y hasta ser deportados muchos de sus habitantes a Babilonia, donde el pueblo judio pasará más de 50 años como exiliado.

\section{Exilio en Babilonia ( 550 a.C.)}

Tenemos al pueblo judio en el exilio. Allí, y ya mirando hacia la posibilidad de un retomo a la tierra, un grupo de sacerdotes va revisando las leyes antiguas y va redactando un nuevo código, el llamado Código o Ley de Santidad. En estc código, se vuelven a encontrar varias leyes en defensa de los derechos humanos; y esto vuelve a ser una demostración de que en el pueblo surgido del éxodo y de la experiencia del Dios liberador, siempre se vio como fundamental el que las relaciones sociales y comunitarias se basasen en la defensa de los derechos que ayudasen a vivir dignamente a los hombres y mujeres del pueblo. De ahí la insistencia en las leyes que defendiesen tales derechos humanos. Veamos, como en un índice, algunas de tales leyes. Seguiremos también en este caso la misma agrupación por temas de los dos códigos analizados anteriormente.

\section{a) Sobre la libertad y la esclavitud}

Lv 19, 29: Deber de no profanar a la hija dándola a la prostitución y haciéndole perder así su liberlad y su vida digna.

Lv 25, 8ss: Deber, en el año jubilar, de liberar a todos los esclavos (v.

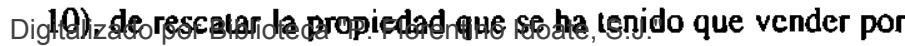
Universidad Centroamericana José Simeón Cañas 
necesidad (vv. 13-15), de rescatar la tierra o bien el goel o bien el mismo que ha tenido que venderla (vv. 23-28), de rescatar la vivienda (vv. 29-31), de no prestar a interés o usura al hermano empobrecido ( $v v .35-37$ ), de no convertir en esclavo al que se ha empobrecido (vv. 39-43), de rescatar al pobre que se ha tenido que poner al servicio de un extranjero (vv. 47-54).

Lv 26,13: Deber de no esclavizar a los demás, ya que Yahveh los sacó de la esclavitud.

b) Sobre la vida

Lv 19, 16: Deber de no difamar ni demandar conura la vida del prójimo.

c) Sobre el respeto a los padres y ancianos

Lv 19. 3: $\quad$ Deber de respetar a los padres.

Lv 19, 32: Deber de respetar las canas, es decir, la ancianidad.

e) Sobre el cuidado por aplicar bien y matizadamente la justicia

Lv $19,15:$ Deber del juez de hacer auténtica justicia sin favorecer a quien no liene la razón.

Lv 19, 35-36: Deber de ser justo en los juicios y en las transacciones comerciales.

Lv 24, 17-22: Derecho y deber a que se cumpla la ley del talión como muestra de la preocupación por la justicia en casos de lesiones o muerte producida al prójimo o a sus animales.

n) Sobre los pobres y marginados

Lv 19, 9-10: Derecho del pobre y cl inmigrante a beneficiarse con aquello que quede en los campos de cultivo.

Lv 19. 14: Deber de no maldecir al mudo ni poner tropiezos al ciego, pues no se pueden defender.

Lv 19, 33-34: Deber de no molestar al inmigrante, de mirarle como a uno del propio pueblo y de amarle como a uno mismo.

Lv 23, 22: Derecho del pobre y del inmigrante a lo que quede en los campos de cultivo.

Lv 25, 1-7: Deber de dejar descansar la tierra cada siete años; lo que produzca naturalemente durante dicho año sabático es en beDigitalizado por Biblioteca "P. Florentino Idoate, S.J." 
neficio de los pobres (los esclavos, los jomaleros, los inmigrantes).

Lv 25, 8ss: Deber, en el año jubilar, de liberar a lodos los esclavos (v. 10), de rescatar la propiedad que se ha tenido que vender por necesidad (vv. 13-15), de rescatar la uierta o bien el goel o bien el mismo que ha tenido que venderla (vv. 23-28), de rescatar la vivienda (vv. 29-31), de no prestar a interés o usura al hermano empobrecido (vv. 35-37), de no convertir en esclavo al que se ha empobrecido (vv. 39-43), de rescatar al pobre que se ha tenido que poner al servicio de un extranjero (vv. 47-54).

Como se ve en todo este apartado. uno de los grupos humanos que más desfavorecido debía estar y que por esto mereció que se legislase mucho sobre él para defenderlo es el grupo de los inmigrantes.

Dos textos de dos profetas del tiempo del exilio insisten también significativarnente en los derechos de los inmigrantes en la nueva situación que se creará a partir del exilio; se trata del Segundo Isalas y de Ezequiel.

Sí, Yahveh se compadecerá de Jacob, se lijará de nuevo en Israel y volverá a instalarlo en su patria. El inmigrante seguirá también sus pasos y se juntará a los de la Tamilia de Jacob (Is 14, 1).

Sortearán la tierra para herencia de ustedes y de los inmigrantes que se unan a ustedes y tengan hijos entre ustedes. A ellos deben mirarlos como del mismo pueblo de los hijos de Israel: sortearán la tierra con ustedes y tendrán su herencia en medio de las tribus de Israel (Ez 47, 22).

I) Sobre el salario justo

Lv 19,13: Deber de no oprimir al prójimo, no despojarlo y no retener su salario.

m) Sobre la honradez comercial

Lv 19, 35-36: Deber de ser justo en los juicios y en las transacciones comerciales.

\section{n) Sobre la verdad}

Lv 19, 11: Deber de no robar, no mentir y no defraudar.

Lv 19, 16: Deber de no difamar ni demandar conura la vida del projimo. 
n) Sobre el amor al prójimo

Lv 19, 17: Deber de no odiar en el corazón al hermano, aunque sí de corregirlo con caridad.

Lv 19, 18: Deber de no vengarse ni guardar rencor, sino de amar al prójimo como a uno mismo.

\section{EI postexilio ( 400 a.C.)}

Tras el regreso del exilio, de nuevo se dicron situaciones en que los derechos humanos volvieron a ser violados gravemente; esto provocó inmedialamente el surgimiento de profelas, como Zacarias y Malaquías, que se convirueron en los defensores de dichos derechos. Vcamos algunos tcxtos.

A favor de la justicia y de la solidaridad:

Pues bien, esto es lo que Yahveh dccía por sus proletas y ahora me cncarga de repelírselo a ustedes: "Actúcn siempre con sinceridad. Sean buenos y compasivos con sus hermanos. No opriman a la viuda ni al huérfano, al inmigrante ni al pobre; no anden pensando cómo hacerle mal al otro" ( $\mathrm{Za} 7$, 9-10).

A favor de la paz. y contra la guerra:

Salta, llena de gozo, oh hija de Sión. Lanza gritos de alegría, hija de Jerusalén. Pucs tu rey viene hacia ti; él es santo y victorioso, humilde, y va montado sobre un burro, sobre el hijo pequeño de una burra. Destruirá los carros de Efraím y los caballos de Jerusalén. Desaparecerá el arco con flechas y dictará la paz a las naciones (Za 9, 9-10).

A favor de la verdad, de la autenticidad y de la justicia:

Así amenaza Yahveh de los ejércitos: Me instalaré entre ustedes para hacer justicia y exigiré un castigo inmediato para los hechiceros y los adúlteros, para los que hacen falsos juramentos, para los que abusan del asalariado, de la viuda y del huérfano, para los que no respetan los derechos del inmigrante, y hacen todo esto sin inmutarse (Ma 3,5).

En esta misma línea, Isaías 58 (Tercer Isaías) insiste en que todo les va mal porque mientras hacen ayunos y dicen respetar a Dios, están buscando con gran ambición su propio negocio y enriquecimiento, explotan a los trabajadores sin pagarles el salario, ponen lazos y trampas a los jusios, convienten a los otros en esclavos y no comparten solidariamente lo que poseen con aquellos que carecen de wodo.

Y en el mismo texto de Isaías 58 así como en el de Isaras 61, 1ss, el profeta habla con fuerza en favor del derecho a la liberación y a la solidaridad plena; tanto, que para esta liberación y esta instalación de la solidaridad se dice que ha 
sido enviado cl siervo de Dios:

El Espíritu del Scr̃or Yahveh está sobre mí. Yahveh me ha ungido. Me ha enviado con buenas nolicias para los humildes, para sanar los corazones heridos, para anunciar a los desterrados su liberación, y a los presos su vuclia a la luz., para publicar un año feliz, lleno de los favores de Yahveh, y el día del desquite de nuestro Dios. Me envió para consolar a los que lloran y darles a todos los anligidos de Sión una corona en vez. de ccniza, el aceile de los días alegres en lugar de ropa de luto, cantos de [clicidad en vez de pesimismo (Is 61, 1-3).

Y Baruk, años más tarde, insiste en cosas parecidas cuando intentando caracterizar a los ídolos dice que éstos son los que no pueden librar a un hombre de la mucrle ni amparar al débil contra cl poderoso. No restituyen la vista a ningun ciego ni sacarán de la miscria a nadie. No se compadecerán de la viuda ni serán bienhechores de los huérfanos (Ba 6, 36-37).

No quicro ahora cnurar en la reflexión sapiencial. Pero sí quicro decir que también cn clla cncontramos, en otra forma, las mismas enseñanzas sobre la necesidad de defender los derechos humanos. Se pueden cotcjar los siguientes texlos: Job 29, 12-17; 30, 24-25; 31, 5-6.13-22.24-25.31-32.38-39; Sir 4, 1-10 (deber de comparlir con el pobre); Sir 7, $32-36$ (deber de solidarizarse con el pobre y con el que sufre); Sir 29, 8-13 (deber de compartir con el pobre; Sir 34, 18-35, 24 (dclinición de cuáles son los sacrificios que le gustan a Dios; a saber, la conducta justa y misericordiosa); Tob 4, 3-20 (deber de ser justo y solidario si es que uno quiere ser considerado amigo de Dios).

\section{Relación entre lo anterior y el Nuevo Testamento}

Todo lo anterior ha sido sacado del estudio del Anliguo Testamento, es decir, de lo que se llama de otro modo "la ley y los profetas". Nos hacemos ahora la pregunta sobre si el Nuevo Testamento sigue en la misma línea.

La respuesta es, a mi parecer, que más todavía. De hecho en el Nuevo Testamento:

* se asume lo anterior, tal como aparece en Romanos 3,21 ("Pero ahora... la justicia de Dios se ha manifestado atestiguada por la ley y los profetas, justicia de Dios por la fe en Jesucristo"), en Mateo 5 (y toda su recuperación profunda de la ley) y en Mateo 7,12 ("Por tanto, todo cuanto quieran que les hagan los hombres, háganselo también ustedes a ellos; porque ésta es la ley y los profetas").

" se radicaliza, tal como aparece en Juan 13, 34 ("Les doy un mandamiento nuevo: que se amen los unos a los otros. Que como yo les he amado, así se amen ustedes los unos a los otros"). 
- se realiza en Jesús, tal como aparece en Lucas 4, 16-30 (el discurso programático de Jesús en la sinagoga de Nazaret), en Lucas 7, 18-23 (la respuesta de Jesús ante la pregunta que le hacen de parte de Juan el Bautista sobre si es el cl que había de venir o se tenia que scguir esperando a otro; esta respuesta va en la línca de que sí cs él y que es reconocible por los actos de liberación en lavor de los desprotegidos) y en Mateo 11, 2-6 (lo mismo que el texto anterior).

* se espera que continúc por parte de los seguidores de Jesús, tal como aparece en Mateo 25, 31-46 (el critcrio de salvación en el juicio final es la conducta que se haya tenido con los maltratados, los pobres y los marginados), en los Hechos de los Apóstoles (las acciones de los apóstoles en favor de los enfermos y los pobres), en Pablo (su mensaje en favor de todos los seres humanos incluidos los extranjeros, aunque para cllo se tenga que oponer al mismo Pedro), en Pablo (su defensa del esclavo Onésimo ante su amo Filemón), en Santiago (su defensa de la justicia social).

\section{Conclusión}

Este sencillo estudio del tema de los derechos humanos en el Antiguo Testamento (poniendo mayor insistencia en la ley y en los profetas) nos hace descubrir, y esto es lo más importante, que para la gente creyente del pucblo de Dios fue fundamental la defensa de dichos derechos. Vio siempre su cumplimiento como el crilerio para poder decir que se estaba viviendo de verdad la relación con el Dios que les había constituido como pueblo uras la liberación del dominio egipcio; y vio su incumplimicnto como el criterio para poder decir que la relación que se estaba teniendo con dicho Dios era totalmente falsa e hipócrita.

Si no nos quedamos en la letra de las leyes de los códigos del Antiguo Testamento, de las palabras proféticas y de las reflexiones sapienciales, aparece claro y manificsto que los derechos defendidos mediante dichas formulaciones, están muy cercanos a los que hoy dia llamamos nosotros "derechos humanos". sobre todo en lo que se refiere a su "espíritu".

Así, pues, la defensa de los derechos humanos actualmente, en momentos en que en la sociedad no hay demasiados remordimientos en lo que a este tema se refiere y en que tantas veces se violan abierta o solapadamente ( $c f r$. segregación racial, abandono de los grupos más pobres, injusticia siempre en favor de los poderosos, marginación de quienes molestan en el desarrollo de la sociedad, etc., etc.), nos queda como una tarea que no sólo es humana, sino que también es divina en cuanto que se enraiza, como hemos visto, en la experiencia originaria del Dios liberador. 